\title{
The effects of a garlic oil chemical compound, propyl-propane thiosulfonate, on ruminal fermentation and fatty acid outflow in a dual-flow continuous culture system
}

\author{
A. Foskolos, ${ }^{*}$ A. Siurana, ${ }^{*}$ M. Rodriquez-Prado, ${ }^{*}$ A. Ferret, ${ }^{*}$ D. Bravo, $\dagger$ and S. Calsamiglia* \\ *Animal Nutrition, Management and Welfare Research Group, Departament de Ciència Animal i dels Aliments, \\ Universitat Autònoma de Barcelona, 08193 Bellaterra, Spain \\ †Pancosma SA, 1218 Geneva, Switzerland
}

\begin{abstract}
The ban on the use of antibiotics as growth promoters in animal feeds in the European Union has stimulated research on potential alternatives. Recently, propylpropane thiosulfonate (PTSO), a stable organosulfurate compound of garlic, was purified. The objectives of the current study were to investigate the potential effects of PTSO on rumen microbial fermentation and to define effective doses. Two experiments were conducted using dual-flow continuous culture fermenters in 2 replicated periods. Each experimental period consisted of $5 \mathrm{~d}$ for adaptation of the ruminal fluid and $3 \mathrm{~d}$ for sampling. Temperature $\left(39^{\circ} \mathrm{C}\right), \mathrm{pH}(6.4)$, and liquid $\left(0.10 \mathrm{~h}^{-1}\right)$ and solid $\left(0.05 \mathrm{~h}^{-1}\right)$ dilution rates were maintained constant. Samples were taken $2 \mathrm{~h}$ after feeding and from the 24-h effluent. Samples were analyzed for volatile fatty acids (VFA) and nitrogen fractions, and degradation of nutrients was calculated. In addition, 24-h effluents from experiment 2 were analyzed for their fatty acid (FA) profile. Treatments in experiment 1 included a negative control without additive, a positive control with monensin $(12 \mathrm{mg} / \mathrm{L})$, and PTSO at 30 and 300 $\mathrm{mg} / \mathrm{L}$. The addition of $30 \mathrm{mg} / \mathrm{L}$ did not affect any of the measurements tested. The addition of $300 \mathrm{mg} / \mathrm{L}$ reduced microbial fermentation, as suggested by the decreased total VFA concentration, true degradation of organic matter and acid detergent fiber, and a tendency to decrease neutral detergent fiber degradation. Experiment 2 was conducted to test increasing doses of PTSO $(0,50,100$, and $150 \mathrm{mg} / \mathrm{L})$ on rumen microbial fermentation. At $2 \mathrm{~h}$ postfeeding, total VFA and molar proportion of propionate responded quadratically, with higher values in the intermediate doses. Molar proportions of butyrate increased and branched-chain VFA decreased linearly as the dose of PTSO increased. In the 24-h effluents, total VFA, acetate, and branched-
\end{abstract}

Received July 28, 2014.

Accepted April 8, 2015.

${ }^{1}$ Corresponding author: Sergio.Calsamiglia@uab.cat chain VFA concentrations decreased linearly and those of propionate responded cubically with the highest value at $100 \mathrm{mg} / \mathrm{L}$. Saturated FA decreased and unsaturated FA increased linearly with increasing dose of PTSO. The concentration of trans-10, cis-12 conjugated linoleic acid decreased by $78.5 \%$ with addition of PTSO at the highest dose $(150 \mathrm{mg} / \mathrm{L})$. Results suggest the potential of PTSO to modify ruminal fermentation in a direction consistent with higher propionate molar proportion, higher outflow of unsaturated FA, and low trans-10, cis-12 conjugated linoleic acid in an effective dose between 50 and $100 \mathrm{mg} / \mathrm{L}$.

Key words: essential oil, fatty acid, garlic oil, rumen fermentation

\section{INTRODUCTION}

The ban on the use of antibiotics as growth promoters in animal feeds in the European Union (European Commission, 2003) has stimulated research on potential alternatives. Among them, essential oils seem promising because of their antimicrobial properties (Cowan, 1999). Garlic oil is a complex mix of many different compounds present in the plant or derived from processing and it has antimicrobial activity against a wide spectrum of bacteria (Calsamiglia et al., 2007). Several in vitro fermentation trials with rumen fluid reported that garlic oil reduced concentrations of acetate, branched-chain VFA (BCVFA), and ammonia-N, and increased concentrations of propionate and butyrate (Cardozo et al., 2004; Busquet et al., 2005a,b, 2006). Busquet et al. (2005b) investigated the effects of garlic oil and 4 of its main active compounds and found that diallyl disulfide and allyl mercaptan were the major compounds responsible for its action. However, chemical instability of these compounds may reduce the effectiveness of garlic oil in field conditions (Lawson and Gardner, 2005; Fujisawa et al., 2008).

Recently, 2 stable organosulfurate compounds of garlic have been purified (Lara Cambil and Garcia-Pareja, 2006): propyl-propane thiosulfinate (PTS) and propyl- 
propane thiosulfonate (PTSO). The compounds are structurally similar and differ only in the presence of one more oxygen function in PTSO. These compounds were first tested in vitro using goat rumen fluid and results suggested that they could be used to modify ruminal fermentation (Martínez-Fernández et al., 2013). Further, Ramos-Morales et al. (2013) tested the effects of PTS in continuous culture fermenters inoculated with goat rumen fluid and reported moderate increases in PUFA and trans-10 C18:1 concentrations in the 24-h effluent, suggesting the potential of garlic oil compounds to modify lipolysis and biohydrogenation in the rumen. However, PTSO demonstrated a stronger antimicrobial activity than PTS when tested in the gastrointestinal microbiota of pigs (Ruiz et al., 2010). The objective of the current study was to investigate the potential effects of PTSO on rumen microbial fermentation and FA profile in a dual-flow continuous culture system.

\section{MATERIALS AND METHODS}

\section{Apparatus and Experimental Design}

Eight 1,320-mL dual-flow continuous culture fermenters developed by Hoover et al. (1976) were used in 2 replicated periods. Each experimental period consisted of $5 \mathrm{~d}$ for adaptation of the rumen fluid to treatments and $3 \mathrm{~d}$ for sampling.

On the first day of each period, rumen fluid was taken from a dry Holstein cow (625 kg of BW) fed a $60 \%$ forage and $40 \%$ concentrate (DM basis) diet, using a probe connected to an automated vacuum pump. Rumen fluid from 5 different locations was collected into two 5-L thermoses under $\mathrm{CO}_{2}$ flushing to maintain anaerobic conditions. Upon arrival at the laboratory, collected rumen fluid was filtered through 2 layers of cheesecloth to remove large feed particles, and then it was used, undiluted, to inoculate fermenters. Fermentation conditions were maintained constant with a temperature of $39^{\circ} \mathrm{C}$, and $\mathrm{pH}$ at $6.4 \pm 0.05$ controlled by infusions of $3 \mathrm{~N} \mathrm{HCl}$ or $5 \mathrm{~N} \mathrm{NaOH}$, and monitored by a computer and a Programmable Linear Controller (FieldPoint, National Instruments, Austin, TX). Anaerobic conditions were maintained by the infusion of $\mathrm{N}_{2}$ gas at a rate of $40 \mathrm{~mL} / \mathrm{min}$. Artificial saliva (Weller and Pilgrim, 1974) was continuously infused into flasks and contained $0.4 \mathrm{~g} / \mathrm{L}$ of urea to simulate recycled $\mathrm{N}$. Liquid and solid dilution rates were set at 0.10 and 0.05 $\mathrm{h}^{-1}$, respectively.

Experiment 1. All fermenters were fed $95 \mathrm{~g} / \mathrm{d}$ of DM of the diet (17\% CP, $27 \% \mathrm{NDF}, 15 \% \mathrm{ADF} ; 3.2 \%$ fat; DM basis) in 3 equal portions at 0700,1500 , and 2300 $\mathrm{h}$. The diet was ground to pass a $1.5-\mathrm{mm}$ screen (SM 2000, Retsch GmbH, Haan, Germany) and consisted
(DM basis) of alfalfa hay (23.7\%), corn silage (30.5\%), ground corn grain $(29.6 \%)$, soybean meal $(15.4 \%)$, and a vitamin and mineral mixture $(0.8 \%)$. The vitamin and mineral mixture contained per kilogram of DM: $300 \mathrm{~g}$ of $\mathrm{MgO} ; 267 \mathrm{~g}$ of urea; $33 \mathrm{~g}$ of sulfur; $67 \mathrm{~g}$ of $\mathrm{NaCl}$; 4,660 $\mathrm{mg}$ of $\mathrm{Zn} ; 2,660 \mathrm{mg}$ of $\mathrm{Mn} ; 167 \mathrm{mg}$ of $\mathrm{Cu} ; 27 \mathrm{mg}$ of Se; $33 \mathrm{mg}$ of I; $7 \mathrm{mg}$ of Co; 1,000 kIU of vitamin A; $200 \mathrm{kIU}$ of vitamin $\mathrm{D}_{3}$; and 1,330 $\mathrm{mg}$ of vitamin $\mathrm{E}$.

Treatments included a negative control without additive (CTR), a positive control with monensin at $12 \mathrm{mg} / \mathrm{L}$ (MON; Sigma-Aldrich Chemical, St. Louis, MO) and 2 doses of PTSO (Pancosma SA, Geneva, Switzerland) at $30 \mathrm{mg} / \mathrm{L}$ (PTSO30) and $300 \mathrm{mg} / \mathrm{L}$ (PTSO300). Treatments were incorporated directly into the fermenter fluid $1 \mathrm{~min}$ before each feeding. Daily doses of PTSO30, PTSO300, and MON were dissolved in $1.2 \mathrm{~mL}$ of ethanol, and fermenters with the CTR treatment were supplied with $1.2 \mathrm{~mL}$ of ethanol in 3 doses daily.

Experiment 2. All fermenters were fed $95 \mathrm{~g} / \mathrm{d}$ of $\mathrm{DM}$ of the diet $(17 \% \mathrm{CP}, 30 \% \mathrm{NDF}, 19 \% \mathrm{ADF} ; 3.2 \%$ fat; DM basis) in 3 equal portions at 0700,1500 , and $2300 \mathrm{~h}$. The diet was ground to pass a $1.5-\mathrm{mm}$ screen (SM 2000, Retsch GmbH) and consisted (DM basis) of alfalfa hay $(34.6 \%)$, corn silage $(21.3 \%)$, ground corn grain $(31.5 \%)$, soybean meal $(12.0 \%)$, and the same vitamin and mineral mixture $(0.8 \%)$ as in experiment 1 . Treatments included a control without additive (PTSO0), and PTSO at $50 \mathrm{mg} / \mathrm{L}$ (PTSO50), $100 \mathrm{mg} / \mathrm{L}$ (PTSO100), and $150 \mathrm{mg} / \mathrm{L}$ (PTSO150). Treatments were incorporated directly into the fermenter fluid $1 \mathrm{~min}$ before each feeding. Daily doses of PTSO50, PTSO100, and PTSO150 were dissolved in $1.2 \mathrm{~mL}$ of ethanol, and fermenters with the PTSO0 treatment were also supplied with $1.2 \mathrm{~mL}$ of ethanol in 3 doses daily.

\section{Sample Collection}

During the last $3 \mathrm{~d}, 40 \mathrm{~mL}$ of filtered fermenter fluid was taken $2 \mathrm{~h}$ after the morning feeding to determine the concentrations of ammonia-N and VFA, trichloroacetic acid-soluble N (TCA-N), and tungstic acid-soluble N (TA-N). Results were used to calculate large peptides $($ LPep $=$ TCA-N - TA-N), small peptides plus amino acids $($ SPep $=$ TA-N - ammonia-N), and ammonia- $\mathrm{N}$ concentrations in fermenters (Winter et al., 1964).

During sampling days, effluent collection vessels were maintained at $4^{\circ} \mathrm{C}$ to prevent microbial activity. Solid and liquid effluents were mixed and homogenized for 1 min at 24,000 rpm (Diax900, Heidolph, Nurnberg, Germany), and a $500-\mathrm{mL}$ sample was removed by aspiration and frozen at $-20^{\circ} \mathrm{C}$. Upon completion of each period, effluents from the 3 sampling days were composited 
and mixed within fermenter, and homogenized for 1 min. Subsamples were taken for total N, ammonia-N, VFA, TCA-N, and TA-N analyses. The remainder of the sample was lyophilized. Dry samples were analyzed for DM, ash, NDF, ADF, FA, and purine contents.

Bacterial cells were obtained from fermenter flasks on the last day of each experimental period. Solid- and liquid-associated bacteria were isolated using a combination of several detachment procedures (Whitehouse et al., 1994), selected to obtain maximum detachment without affecting cell integrity. One hundred milliliters of a $2 \mathrm{~g} / \mathrm{L}$ methylcellulose solution and small marbles (30 of $2 \mathrm{~mm}$ diameter and 15 of $4 \mathrm{~mm}$ diameter) were added to each fermenter, incubated in the same fermenter flasks at $39^{\circ} \mathrm{C}$, and mixed for $1 \mathrm{~h}$ to remove attached bacteria. After incubation, fermenter flasks were refrigerated for $24 \mathrm{~h}$ at $4^{\circ} \mathrm{C}$, and fermenter contents were agitated for $1 \mathrm{~h}$ to dislodge loosely attached bacteria. Finally, the fermenter content was filtered through cheesecloth and washed with saline solution $(8.5 \mathrm{~g} / \mathrm{L}$ $\mathrm{NaCl}$ ). Bacterial cells were isolated within $4 \mathrm{~h}$ by differential centrifugation at $1,000 \times g$ for 10 min to separate feed particles, and the supernatant was centrifuged at $20,000 \times g$ for 20 min to isolate bacterial cells. Pellets were rinsed twice with saline solution and recentrifuged at $20,000 \times g$ for $20 \mathrm{~min}$. The final pellet was recovered with distilled water to prevent contamination of bacteria with ash. Bacterial cells were lyophilized and analyzed for DM, ash, N, and purine contents. Digestion of DM, OM, NDF, ADF, and CP, and flows of total, nonammonia, microbial, and dietary $\mathrm{N}$ were calculated as described by Stern and Hoover (1990).

\section{Chemical Analysis}

Effluent DM was determined by lyophilizing 300-mL aliquots in triplicate. The DM content of diets and bacterial samples was determined by drying samples for $24 \mathrm{~h}$ in a $103^{\circ} \mathrm{C}$ forced air oven (AOAC, 1990). Dry samples of diets, effluents, and bacteria were ashed overnight at $550^{\circ} \mathrm{C}$ in a muffle furnace (AOAC, 1990; method 942.05), and OM was determined by difference. Neutral detergent fiber components of diets and effluents were analyzed sequentially (Van Soest et al., 1991) using a heat-stable $\alpha$-amylase and sodium sulfite, and expressed without residual ash, and ADF expressed exclusive of residual ash. Total $\mathrm{N}$ content of diets, effluents, and bacterial samples was determined by a Kjeldahl method (AOAC, 1990; method 976.05). Sample CP was calculated as $\mathrm{N} \times 6.25$.

Peptide and amino acid $\mathrm{N}$ were determined as described by Winter et al. (1964). To determine TCA-N, $4 \mathrm{~mL}$ of a $500 \mathrm{~g} / \mathrm{L}$ TCA solution were added to $16 \mathrm{~mL}$ of filtered fermenter fluid. After $4 \mathrm{~h}$ at $5^{\circ} \mathrm{C}$, tubes were centrifuged at $9,000 \times g$ for $15 \mathrm{~min}$. The supernatant was stored and frozen until analyzed for TCA-N by the Kjeldahl procedure (AOAC, 1990; method 976.05). To determine TA-N, $4 \mathrm{~mL}$ of a $100 \mathrm{~g} / \mathrm{L}$ sodium tungstate solution and $4 \mathrm{~mL}$ of $1.07 \mathrm{~N}$ sulfuric acid were added to a $16-\mathrm{mL}$ sample of filtered fermenter fluid. After $4 \mathrm{~h}$ at $5^{\circ} \mathrm{C}$, tubes were centrifuged at $9,000 \times g$ for $15 \mathrm{~min}$. The supernatant was stored and frozen until it was analyzed for TA-N by the Kjeldahl procedure (AOAC, 1990; method 976.05).

Ammonia- $\mathrm{N}$ was analyzed by colorimetry as described by Chaney and Marbach (1962), where $4 \mathrm{~mL}$ of a $0.2 \mathrm{~N} \mathrm{HCl}$ solution was added to $4 \mathrm{~mL}$ of filtered rumen fluid and frozen. Samples were centrifuged at $3,000 \times g$ for $20 \mathrm{~min}$, and the supernatant was used to determine ammonia-N by spectrophotometry (Libra S21, Biochrom Technology, Cambridge, UK).

Samples for VFA analysis were prepared as described by Jouany (1982) and analyzed by gas chromatography: $1 \mathrm{~mL}$ of a solution made up of a $2 \mathrm{~g} / \mathrm{L}$ solution of mercuric chloride, $2 \mathrm{~g} / \mathrm{L}$ of 4 -methylvaleric acid as an internal standard, and $20 \mathrm{~g} / \mathrm{L}$ orthophosphoric acid, was added to $4 \mathrm{~mL}$ of filtered rumen fluid and frozen. Samples were centrifuged at $15,000 \times g$ for $15 \mathrm{~min}$, and the supernatant was analyzed by gas chromatography (model 6890, Hewlett Packard, Palo Alto, CA) using a polyethylene glycol nitroterephthalic acid-treated capillary column (BP21, SGE, Europe Ltd., Bucks, UK). Samples of lyophilized effluents and bacterial cells were analyzed for purine content (adenine and guanine) by HPLC as described by Makkar and Becker (1999), using allopurinol as the internal standard.

Fatty acids were determined in $250 \mathrm{mg}$ of freeze-dried sample, as described by Vlaeminck et al. (2014). Briefly, toluene $(2 \mathrm{~mL})$ containing the internal standard (13:0; $0.4 \mathrm{mg})$ and methanolic $\mathrm{NaOH}(2 \mathrm{~mL})$ were added and the mixture was incubated at $70^{\circ} \mathrm{C}$ for $60 \mathrm{~min}$, followed by 30 min at $50^{\circ} \mathrm{C}$ after the addition of methanolic $\mathrm{HCl}$ (3 $\mathrm{mL}$; prepared by dissolving $10 \mathrm{~mL}$ of acetyl chloride in $50 \mathrm{~mL}$ of methanol). Fatty acid methyl esters were extracted with hexane. Composition analyses of FA were carried out with a gas chromatograph (6890, Agilent Technologies, Hewlett Packard) equipped with a CP-Sil-88 column $(100 \times 0.25 \mathrm{~mm}$ i.d. $\times 0.2 \mu \mathrm{m}$; Varian Inc., Mississauga, ON, Canada). The temperature program was $70^{\circ} \mathrm{C}$ for $1 \mathrm{~min}$, followed by an increase of $1^{\circ} \mathrm{C} / \mathrm{min}$ to $225^{\circ} \mathrm{C}$, and then maintained for $15 \mathrm{~min}$. Inlet and detector temperatures were $250^{\circ} \mathrm{C}$ and $255^{\circ} \mathrm{C}$, respectively. The split ratio was 100:1. The flow rate for hydrogen carrier gas was $40 \mathrm{~mL} / \mathrm{min}$. Fatty acid peaks were identified by comparing retention times with those of the corresponding standards [Supelco 37 Component FAME Mix, cis-11-octadecenoic methyl ester, trans11-octadecenoic methyl ester (Supelco Analytical, 
Table 1. Effect of propyl-propane thiosulfonate (PTSO) and monensin addition on total VFA concentration and VFA profile of 24-h effluent in a dual flow continuous culture (experiment 1$)^{1}$

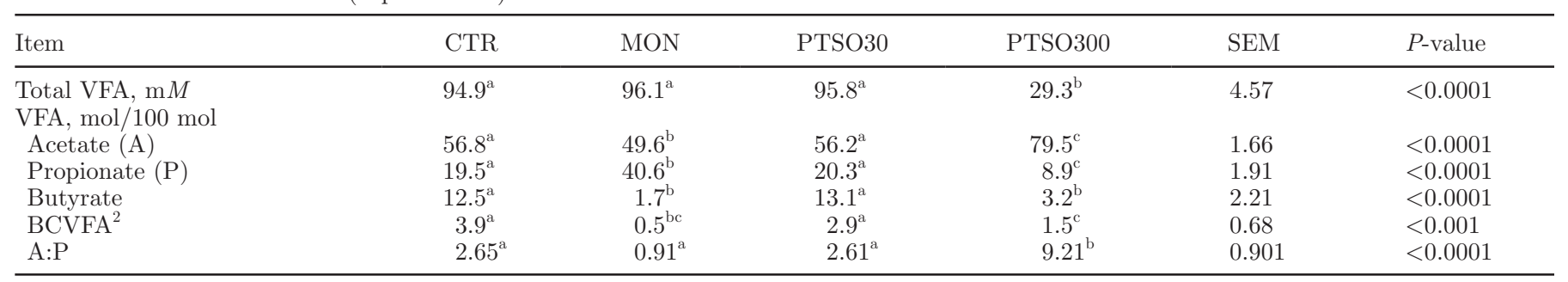

${ }^{\mathrm{a}-\mathrm{c}}$ Within a row, means without a common superscript differ $(P<0.05)$.

${ }^{1} \mathrm{CTR}=0 \mathrm{mg} / \mathrm{L} ; \mathrm{PTSO} 30=30 \mathrm{mg} / \mathrm{L}$ of PTSO; PTSO300 $=300 \mathrm{mg} / \mathrm{L}$ of PTSO; MON = $12 \mathrm{mg} / \mathrm{L}$ of monensin.

${ }^{2} \mathrm{BCVFA}=$ branched-chain VFA.

Bellefonte, PA); linoleic acid, conjugated methyl ester (Sigma-Aldrich Chemical)].

\section{Statistical Analysis}

All statistical analyses were conducted using SAS (version 9.2; SAS Institute Inc., Cary, NC). Results of VFA concentration, $\mathrm{N}$ fractions, nutrient digestion, and flows were analyzed using the PROC MIXED procedure (Littell et al., 1998). The model accounted for the effects of treatment (fixed effect) and period was considered a random effect. In experiment 1, differences between means of treatments were tested using the Tukey option, and significance was declared at $P<$ 0.05 . In experiment 2 , orthogonal contrasts were used to detect linear, quadratic, and cubic responses. Differences were declared significant at $P<0.05$.

\section{RESULTS AND DISCUSSION}

\section{Experiment 1}

Monensin was chosen as a positive control because of its demonstrated effects on ruminal metabolism (Russell and Strobel, 1989). As expected, MON decreased the molar proportion of acetate and increased that of propionate $(P<0.0001$; Table 1$)$ of the 24 -h effluent. Moreover, MON reduced ammonia-N concentration $(P$ $<0.001$; Table 2) at $2 \mathrm{~h}$ postfeeding without affecting overall $\mathrm{CP}$ degradation. However, it reduced true degradation of $\mathrm{OM}$ and $\mathrm{ADF}(P=0.003)$ and tended to reduce NDF degradation $(P=0.072)$. Similar studies with dual-flow continuous culture systems reported that supplementation of the same amount of MON also reduced NDF and ADF digestion, but lower doses (1.25 $\mathrm{mg} / \mathrm{L}$ ) had no effect on ruminal metabolism (Busquet et al., 2005a; Castillejos et al., 2006). Other in vitro studies have demonstrated similar negative effects of MON on fiber digestion (Wallace et al., 1981; Russell and Strobel, 1988). However, in vivo studies did not have these negative effects (Donius et al., 1976). Russell and Strobel (1989) attributed these effects of in vitro studies to the increased sensitivity of some cellulolytic bacteria and longer adaptation time of the in vivo experiments: cellulolytic ruminococci and a cellulolytic strain of Butyrivibrio fibrisolvens were very sensitive in vitro, whereas others, such as Fibrobacter succinogenes, did not demonstrate the same sensitivity. They proposed that the longer adaptation time of the in vivo experiments allows MON-resistant cellulolytic bacteria to replace MON-sensitive bacteria, avoiding the overall decreased digestion of NDF and ADF.

The addition of $30 \mathrm{mg} / \mathrm{L}$ of PTSO did not affect any of the measurements tested, but PTSO300 dramatically decreased the concentration of total VFA in the effluent $(61.9 \%$ lower for PTSO300 compared with CTR; $P$ $<0.0001$; Table 1), indicating inhibition of microbial fermentation. Further, PTSO300 addition increased the molar proportion of acetate and decreased those of propionate and butyrate. On ruminal N metabolism, PTSO300 increased LPep concentration in the 2-h postfeeding $(P=0.001)$ and 24 -h $(P=0.022)$ effluents and increased SPep concentration $(P=0.002)$, suggesting that it reduced peptidolysis (Table 2). However, similar to MON, PTSO300 also reduced true degradation of OM and ADF (Table 2). The addition of 300 $\mathrm{mg} / \mathrm{L}$ of garlic oil (Busquet et al., 2006) or its main active components (Busquet et al., 2005b) in vitro were sufficient to alter ruminal fermentation without affecting degradation of nutrients. Results suggest that the antimicrobial activity of PTSO is stronger than that of garlic oil or its other active components, and less may be required to attain similar effects.

\section{Experiment 2}

The second experiment was conducted to define effective doses of PTSO. True degradation of OM, NDF, and ADF averaged 48.2, 44.0, and 43.0\%, respectively, with no differences between treatments (data not 
Table 2. Effect of propyl-propane thiosulfonate (PTSO) and monensin (MON) addition on nitrogen fractions at $2 \mathrm{~h}$ postfeeding and $\mathrm{N}$ fractions and digestibilities of the 24-h effluents in a dual-flow continuous culture (experiment 1$)^{1}$

\begin{tabular}{|c|c|c|c|c|c|c|}
\hline Item & CTR & MON & PTSO30 & PTSO300 & $\mathrm{SE}$ & $P$-value \\
\hline \multicolumn{7}{|c|}{$2 \mathrm{~h}$ postfeeding, $\mathrm{mg} / 100 \mathrm{~mL}$} \\
\hline Ammonia-N & $6.82^{\mathrm{a}}$ & $1.42^{\mathrm{b}}$ & $6.71^{\mathrm{a}}$ & $5.97^{\mathrm{a}}$ & 0.904 & $<0.001$ \\
\hline LPep- $\mathrm{N}^{2}$ & $0.84^{\mathrm{a}}$ & $3.76^{\mathrm{a}}$ & $3.28^{\mathrm{a}}$ & $11.47^{\mathrm{b}}$ & 1.99 & 0.001 \\
\hline \multicolumn{7}{|c|}{ Effluent, mg/100 mL } \\
\hline Ammonia-N & 7.35 & 2.62 & 6.34 & 7.34 & 1.551 & 0.160 \\
\hline LPep-N & $5.96^{\mathrm{a}}$ & $3.30^{\mathrm{a}}$ & $4.96^{\mathrm{a}}$ & $10.00^{\mathrm{b}}$ & 2.336 & 0.022 \\
\hline $\mathrm{OM}$ & $56.8^{\mathrm{a}}$ & $44.4^{\mathrm{b}}$ & $50.5^{\mathrm{a}}$ & $38.2^{\mathrm{c}}$ & 1.96 & 0.003 \\
\hline $\mathrm{CP}$ & 50.9 & 25.5 & 40.1 & 32.6 & 8.33 & 0.228 \\
\hline \multicolumn{7}{|c|}{ Fiber degradation, $\%$} \\
\hline NDF & $22.2^{\mathrm{a}}$ & $1.3^{\mathrm{b}}$ & $15.3^{\mathrm{a}}$ & $19.5^{\mathrm{a}}$ & 5.30 & 0.073 \\
\hline $\mathrm{ADF}$ & $43.9^{\mathrm{a}}$ & $17.8^{\mathrm{b}}$ & $30.8^{\mathrm{a}}$ & $18.7^{\mathrm{b}}$ & 6.95 & 0.03 \\
\hline EMPS $^{2}$ & 24.8 & 18.3 & 27.2 & 20.7 & 3.29 & 0.325 \\
\hline
\end{tabular}

${ }^{\mathrm{a} c}$ Within a row means without a common superscript differ $(P<0.05)$.

${ }^{1} \mathrm{CTR}=0 \mathrm{mg} / \mathrm{L} ; \mathrm{PTSO} 30=30 \mathrm{mg} / \mathrm{L}$ of PTSO; PTSO $300=300 \mathrm{mg} / \mathrm{L}$ of PTSO; $\mathrm{MON}=12 \mathrm{mg} / \mathrm{L}$ of monensin.

${ }^{2} \mathrm{LPep}=$ large peptides; SPep $=$ small peptides

${ }^{3} \mathrm{EMPS}=$ grams of bacterial $\mathrm{N} / \mathrm{kg}$ of OM truly digested.

shown). Increasing the dose of PTSO caused a quadratic response in total VFA $(P=0.04)$ and the molar proportion of propionate $(P=0.02) 2 \mathrm{~h}$ after feeding, with higher values in the intermediate doses (Figure 1). Moreover, PTSO increased linearly the butyrate molar proportion $(P=0.02)$ and decreased linearly that of BCVFA $(P<0.0001)$. However, responses of the $24-\mathrm{h}$ effluents were not the same (Table 3 ). Total VFA and acetate molar proportion decreased linearly $(P=0.001$ and 0.024 for total VFA and acetate, respectively) with increasing dose of PTSO, and the molar proportion of propionate responded cubically $(P=0.019)$, with the highest value at $100 \mathrm{mg} / \mathrm{L}$. We sampled $2 \mathrm{~h}$ postfeeding because fermentation is at maximum level at that time and it is possible to detect small but important differences of fermentation pattern (Cardozo et al., 2004). However, the 24-h effluent represents a more homogeneous outcome of ruminal fermentation; therefore, the 24-h effluent is a better indicator of the effects of PTSO addition on ruminal fermentation. These results are in agreement with main effects of garlic oil and its compounds. Busquet et al. (2005a,b, 2006) showed in several in vitro fermentation trials with rumen fluid that garlic oil reduced the proportions of acetate and BCVFA and increased those of propionate and butyrate. The linear responses of total VFA and the increased proportion of propionate between 50 and $100 \mathrm{mg} / \mathrm{L}$ suggest that the most effective dose of PTSO might be between 50 and $100 \mathrm{mg} / \mathrm{L}$. Lower concentrations had little or no effect, and higher concentrations seemed to compromise overall microbial activity. Propionate concentration in the rumen is negatively correlated with methane rumen production because it serves as a competitive pathway for $\mathrm{H}_{2}$ use in the rumen (Moss et al., 2000). Busquet et al. (2005b) reported that garlic oil reduced methane concentrations by $73.6 \%$ compared with control in a dual-flow continuous culture fermenter system. Therefore, the increased propionate concentration at 100 $\mathrm{mg} / \mathrm{L}$ suggests the potential of PTSO to modify ruminal fermentation in a direction consistent with lower methane production in the rumen.

Ammonia- $\mathrm{N}$ concentration of the 24-h effluent ranged from 7.89 to $11.36 \mathrm{mg} / 100 \mathrm{~mL}$ for PTSO0 and PTSO150, respectively, without any difference among treatments. Similarly, concentrations of SPep and LPep were not affected by the addition of PTSO either in the 24-h effluent or at $2 \mathrm{~h}$ postfeeding (data not shown). Cardozo et al. (2004) reported that garlic oil reduced ammonia-N and increased SPep concentrations in dualflow continuous culture, suggesting that deamination was inhibited. Ferme et al. (2004), using samples of Cardozo et al. (2004), reported that garlic oil modified the microbial population profile, reducing the population of Prevotella spp. (mainly $P$. ruminicola and $P$. bryantii), the most abundant proteolytic and deaminating bacterium in the rumen (Falconer and Wallace, 1998). However, Busquet et al. (2005a,b) reported only small and variable effects of garlic oil compounds on rumen protein degradation. In the current study, BCVFA decreased linearly both in the 24-h effluent and at $2 \mathrm{~h}$ postfeeding. Early studies indicated that the accumulation of BCVFA in the rumen was due to the oxidative deamination of branched chain AA; namely, isovaline and isoleucine (Annison, 1954; Bryant and Doetsch, 1955; Allison and Bryant, 1963). Therefore, the observed reduction of BCVFA suggests the inhibition of 

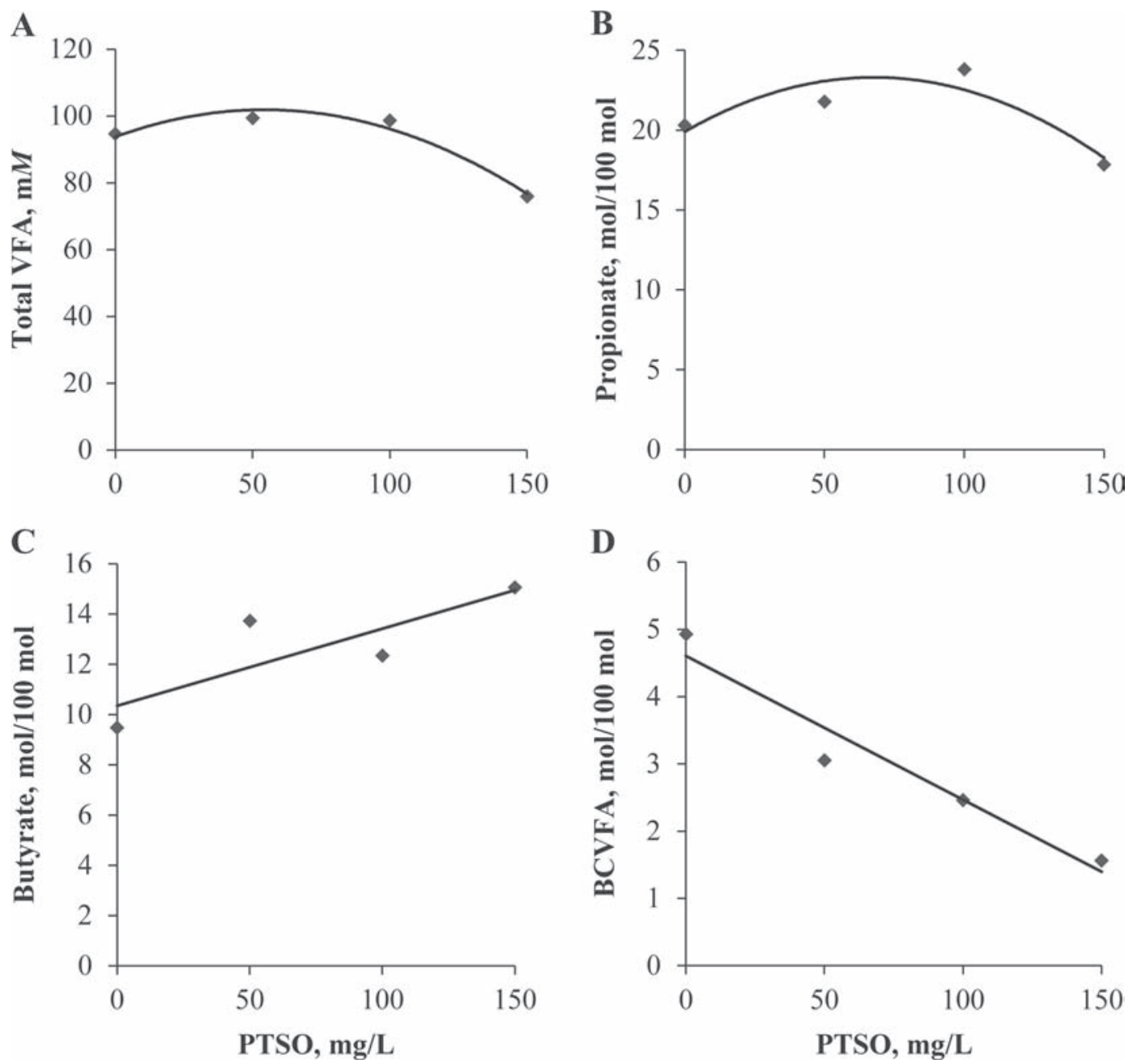

Figure 1. Quadratic $(P<0.05)$ responses of $(\mathrm{A})$ total VFA and $(\mathrm{B})$ propionate molar proportion, and linear $(P<0.05)$ responses of $(\mathrm{C})$ butyrate molar proportion and (D) branched-chain VFA (BCVFA) to increasing dose of propyl-propane thiosulfonate (PTSO; 0, 50, 100, and $150 \mathrm{mg} / \mathrm{L}$ ) at $2 \mathrm{~h}$ postfeeding in a dual-flow continuous culture (experiment 2).

deamination, despite the lack of effect on ammonia-N and SPep.

Table 4 presents effects of increasing dose of PTSO on the 24-h effluent FA flow. The total flow of unsaturated FA (UFA) increased linearly $(P=0.02)$ and that of SFA decreased linearly $(P=0.03)$ with increasing dose of PTSO. When SFA and UFA were expressed as percentages of total FA (Figure 2), the proportion of UFA increased linearly at the expense of SFA with increasing dose of PTSO. For PTSO0, UFA represented 35.9\% of total FA, whereas for PTSO150, UFA represented $60.6 \%$ of total FA, 1.7 times more. Particularly, the addition of PTSO caused a small linear decrease of C15:0, $\mathrm{C} 17: 0$, and anteiso C17:0, and a small linear increase of C16:0 (Table 4). The C17:0 isomers originate from microbial synthesis (Harfoot and Hazlewood, 1997) and their reduction may indicate reduced microbial flow.
The differences in C15:0 and C16:0 flows were not expected because fermenters were fed the same diet. On the other hand, C16:0 is the main FA of rumen bacteria and can represent 24 to $35 \%$ of total bacterial FA (Harfoot and Hazlewood, 1997). Calsamiglia et al. (2007) described the mode of action of essential oil compounds in the rumen microbial environment and suggested that a change in bacterial growth rates results in changes in the proportion of rumen bacterial populations. Different bacterial populations may result in different proportions of C16:0 and C15:0. Therefore, the small differences of C16:0 and C15:0 flows observed in the current study may reflect changes of bacterial populations caused by PTSO addition. However, the exact reason for these effects is not clear.

On the other hand, C18:0 was the main SFA for PTSO0, representing approximately $60 \%$ of total SFA. 
Table 3. Effects of increasing dose of propyl-propane thiosulfonate (PTSO; 0, 50, 100 and $150 \mathrm{mg} / \mathrm{L}$ ) on ammonia-N concentration, total VFA and VFA profile of the 24-h effluent in a dual-flow continuous culture (experiment 2)

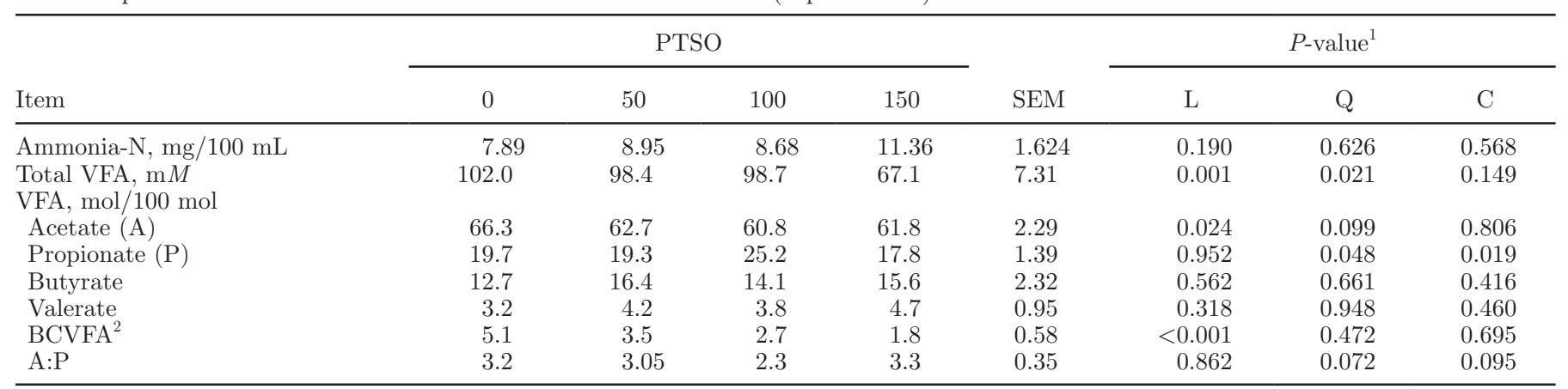

${ }^{1} \mathrm{~L}=$ linear, $\mathrm{Q}=$ quadratic, $\mathrm{C}=$ cubic responses.

${ }^{2} \mathrm{BCVFA}=$ branched-chain VFA.

However, it was only $27 \%$ for PTSO150. In absolute numbers, $712 \mathrm{mg} / \mathrm{d}$ of C18:0 flowed out of the PTSO0 fermenters, whereas only $183 \mathrm{mg} / \mathrm{d}$ flowed out of the PTSO150 fermenters ( $75 \%$ less). In the rumen, dietary UFA are extensively hydrogenated, resulting in the production of C18:0 as the end product of hydrogenation, and in a wide range of isomers of UFA (Chilliard et al., 2007). In the current experiment, the addition of PTSO linearly increased the amount of cis-8 C:16:1, cis-9 C:16:1, C18:1n-9, C18:2n-6, and C18:3n-3 and linearly decreased that of C14:1 and trans-10, cis-12 CLA (Table 4). However, most of the increased UFA was attributed to UFA of dietary origin (C18:1n-9 cis, C18:2n-6, and C18:3n-3; Table 4). At the same time, the flow of UFA plus C18:0 did not differ between treatments and averaged $1,458 \mathrm{mg} / \mathrm{d}$. Therefore, increasing the dose of PTSO reduced biohydrogenation, which resulted in higher outflow of UFA and lower outflow of C18:0.

Biohydrogenation in the rumen is microbial driven (Jenkins et al., 2008; Lourenço et al., 2010). The antimicrobial properties of PTSO were reported previously (Ruiz et al., 2010; Martínez-Fernández et al., 2013) and verified in experiment 1 , where the high dose of PTSO $(300 \mathrm{mg} / \mathrm{L})$ reduced microbial fermentation and digestion of $\mathrm{OM}$ and $\mathrm{ADF}$. In the second experiment, lower doses of PTSO confirmed our observations. Therefore, the reduced biohydrogenation observed with increasing dose of PTSO can be attributed to its antimicrobial properties. Ramos-Morales et al. (2013) investigated the addition of PTS and diallyl disulfide in continuous culture fermenters and also reported an increased proportion of UFA at the expense of SFA and reduced biohydrogenation, resulting in reduced concentration of C18:0 with diallyl disulfide addition. Moreover, they reported no effect on total bacteria amount or the relative abundance of Butyrivibrio proteoclasticus, even though PTS caused an increase of the relative abundance of Butyrivibrio fibrisolvens. However, it should be noted that reported effects on FA concentration are not as severe as those in the current experiment. For example, the addition of PTS reduced SFA by $1.3 \%$ compared with control and C18:0 was not affected. In addition, studies with pig microbiota (Ruiz et al., 2010) suggested that PTSO is a stronger antimicrobial than PTS. The results of the current study suggest that PTSO at doses between 50 and $100 \mathrm{mg} / \mathrm{L}$ can cause significant changes in FA biohydrogenation, altering the flow of SFA and UFA, without affecting overall fermentation. Milk FA composition is of great interest for human nutrition, and several strategies have been proposed to improve FA composition, decreasing SFA and increasing UFA (Chilliard et al., 2006; Givens and Shingfield, 2006). The addition of PTSO in ruminant diets can be an alternative strategy to increase milk UFA; however, further experiments in vivo are needed to confirm this hypothesis.

The pattern of hydrogenation is important not only for the production of a healthy product but also for the animal itself. Bauman and Griinari (2003) proposed the trans-FA theory to explain milk fat depression. According to this theory, rumen intermediates of biohydrogenation, and particularly trans-10 C18:1 and trans-10,cis-12 CLA, inhibit milk fat synthesis in the mammary gland. In the current study, the concentration of trans-10 C18:1 was not affected by PTSO addition but that of trans-10, cis-12 CLA decreased linearly $(P=0.005)$ with increasing doses of PTSO. In fact, the $100 \mathrm{mg} / \mathrm{L}$ dose reduced, by $76.7 \%$, the concentration of trans-10,cis-12 CLA compared with the $0 \mathrm{mg} / \mathrm{L}$ dose (13.3 vs. $3.1 \mathrm{mg} / \mathrm{d}$ for PTSO0 and PTSO100, respectively). Fuentes et al. (2009) reported that low $\mathrm{pH}$ was the main factor affecting biohydrogenation and accumulation of trans-10 C18:1 and trans-10,cis-12 CLA in a dual-flow continuous culture. In the current experiment, $\mathrm{pH}$ was set at $6.4 \pm 0.05$ and controlled by infusions of $3 \mathrm{~N} \mathrm{HCl}$ or $5 \mathrm{~N} \mathrm{NaOH}$; therefore, the reduc- 
Table 4. Effects of increasing dose of propyl-propane thiosulfonate (PTSO; 0, 50, 100 and $150 \mathrm{mg} / \mathrm{L}$ ) on 24-h effluent FA flow (g/d) profile (experiment 2)

\begin{tabular}{|c|c|c|c|c|c|c|}
\hline \multirow[b]{2}{*}{ Item } & \multicolumn{4}{|c|}{ PTSO } & \multirow[b]{2}{*}{ SEM } & \multirow{2}{*}{$\frac{P \text {-value }}{\mathrm{L}}$} \\
\hline & 0 & 50 & 100 & 150 & & \\
\hline C12:0 & 8.1 & 7.3 & 8.4 & 7.7 & 0.67 & 0.995 \\
\hline C14:0 & 20.1 & 17.2 & 18.2 & 13.4 & 2.89 & 0.172 \\
\hline C15:0 & 26.6 & 21.8 & 17.3 & 10.5 & 2.96 & 0.002 \\
\hline $\mathrm{C} 16: 0$ & 324.1 & 329.4 & 365.9 & 383.5 & 13.27 & 0.004 \\
\hline C17:0 & 11.3 & 9.2 & 7.5 & 5.8 & 0.98 & $<0.001$ \\
\hline iso C17:0 & 4.9 & 6.2 & 5.5 & 5.1 & 0.67 & 0.995 \\
\hline anteiso $\mathrm{C} 17: 0$ & 16.9 & 10.7 & 4.7 & 2.2 & 2.30 & $<0.001$ \\
\hline C18:0 & 712.7 & 432.4 & 326.9 & 183.5 & 144.9 & 0.024 \\
\hline C20:0 & 20.1 & 21.1 & 21.3 & 21.1 & 1.34 & 0.608 \\
\hline $\mathrm{C} 22: 0$ & 12.8 & 12.3 & 12.4 & 13.6 & 0.40 & 0.210 \\
\hline $\mathrm{C} 23: 0$ & 8.9 & 8.2 & 9.3 & 8.0 & 0.94 & 0.696 \\
\hline C24:0 & 15.8 & 16.1 & 17.1 & 15.9 & 0.92 & 0.753 \\
\hline Total SFA & 1,188 & 897 & 820 & 676 & 148.2 & 0.029 \\
\hline C14:1 & 39.1 & 34.5 & 25.7 & 13.9 & 4.79 & 0.002 \\
\hline cis-8 C16:1 & 5.3 & 6.1 & 6.6 & 8.6 & 0.89 & 0.006 \\
\hline cis-9 C16:1 & 4.6 & 5.0 & 5.9 & 6.3 & 0.59 & 0.046 \\
\hline C17:1 & 5.9 & 5.3 & 4.8 & 5.7 & 0.91 & 0.335 \\
\hline C18:1n-9 & 174.1 & 219.0 & 244.7 & 271.4 & 27.14 & 0.021 \\
\hline trans-6 C18:1 & 10.0 & 9.4 & 13.3 & 7.5 & 4.36 & 0.830 \\
\hline trans-9 C18:1 & 6.5 & 6.7 & 9.1 & 4.8 & 2.78 & 0.816 \\
\hline trans-10 C18:1 & 22.7 & 25.6 & 27.3 & 18.2 & 7.57 & 0.736 \\
\hline trans-11 C18:1 & 68.2 & 153.0 & 127.0 & 159.9 & 40.7 & 0.292 \\
\hline trans-12 C18:1 & 10.0 & 5.2 & 5.9 & 3.9 & 3.03 & 0.218 \\
\hline cis-11 C:18:1 & 24.2 & 21.1 & 25.6 & 22.1 & 2.06 & 0.844 \\
\hline cis-12 C18:1 & 16.4 & 8.7 & 8.1 & 5.2 & 4.64 & 0.128 \\
\hline C18:2n-6 & 265.8 & 360.2 & 438.4 & 589.0 & 91.9 & 0.008 \\
\hline trans-11,cis-15 C18:2 & 3.6 & 25.0 & 22.3 & 26.7 & 8.52 & 0.108 \\
\hline cis-9,trans-11 CLA & 7.7 & 14.5 & 16.7 & 14.1 & 3.25 & 0.125 \\
\hline trans-10,cis-12 CLA & 13.3 & 8.7 & 3.1 & 2.8 & 4.41 & 0.005 \\
\hline C18:3n-6 & 13.9 & 12.0 & 12.6 & 12.7 & 0.87 & 0.395 \\
\hline C18:3n-3 & 54.7 & 66.8 & 84.0 & 125.1 & 15.6 & 0.001 \\
\hline Total unsaturated FA & 747 & 1,026 & 1,140 & 1,265 & 142.5 & 0.024 \\
\hline Total FA & 1,930 & 1,918 & 1,954 & 1,935 & 56.1 & 0.828 \\
\hline
\end{tabular}

${ }^{1} \mathrm{~L}=$ linear; quadratic and cubic responses were not significant and not reported.

tion of trans-10, cis-12 CLA can be directly attributed to the effects of PTSO.

Chilliard et al. (2007) summarized different biohydrogenation pathways in the rumen and reported that C18:2 biohydrogenation mainly follows the pathway to cis-9,trans-11 C18:2, trans-11 C18:1 before the formation of C18:0. An alternative pathway through trans10,cis-12 CLA, cis-12 C18:1 before the formation of C18:0 was suggested by Bauman and Griinari (2003). Moreover, Wallace et al. (2007) proposed a different biochemical mechanism to synthesize cis-9,trans-11 C18:2 than the formation of trans-10, cis-12 CLA in the rumen. They proposed that Butyrivibrio spp. are mainly responsible for the formation of cis-9,trans-11 C18:2 and Propionibacterium acnes are responsible for the formation of trans-10, cis-12 CLA. In a subsequent study, they reported that Butyrivibrio proteoclasticus has an important role in the synthesis of C18:0 from trans-10 C18:1 (McKain et al., 2010). Calsamiglia et al. (2007) indicated that even though essential oil com- pounds have reduced selectivity against bacteria, some bacterial populations are more sensitive than others. Bacterial specificity of garlic oil against Prevotella spp. has been documented (Ferme et al., 2004). Even though garlic oil is a mix of diverse antimicrobial components, different bacterial specificities of PTS and PTSO may explain why addition of PTS tended to increase trans10,cis-12 CLA concentration of fermenters inoculated with goat rumen fluid (Ramos-Morales et al., 2013), in contrast to our results with PTSO. Even though no bacterial population analysis was conducted in the present experiment, these differences may suggest a potential mode of action of PTSO. It is possible that PTSO affects bacteria responsible for trans-10, cis-12 CLA pathway, such as Propionibacterium acnes, without affecting those that follow the cis-9,trans-11 C18:2 pathway. In fact, several essential oil compounds have been reported to reduce the growth of Propionibacterium acnes in humans (Lang and Buchbauer, 2012), and PTSO is probably one of them. 


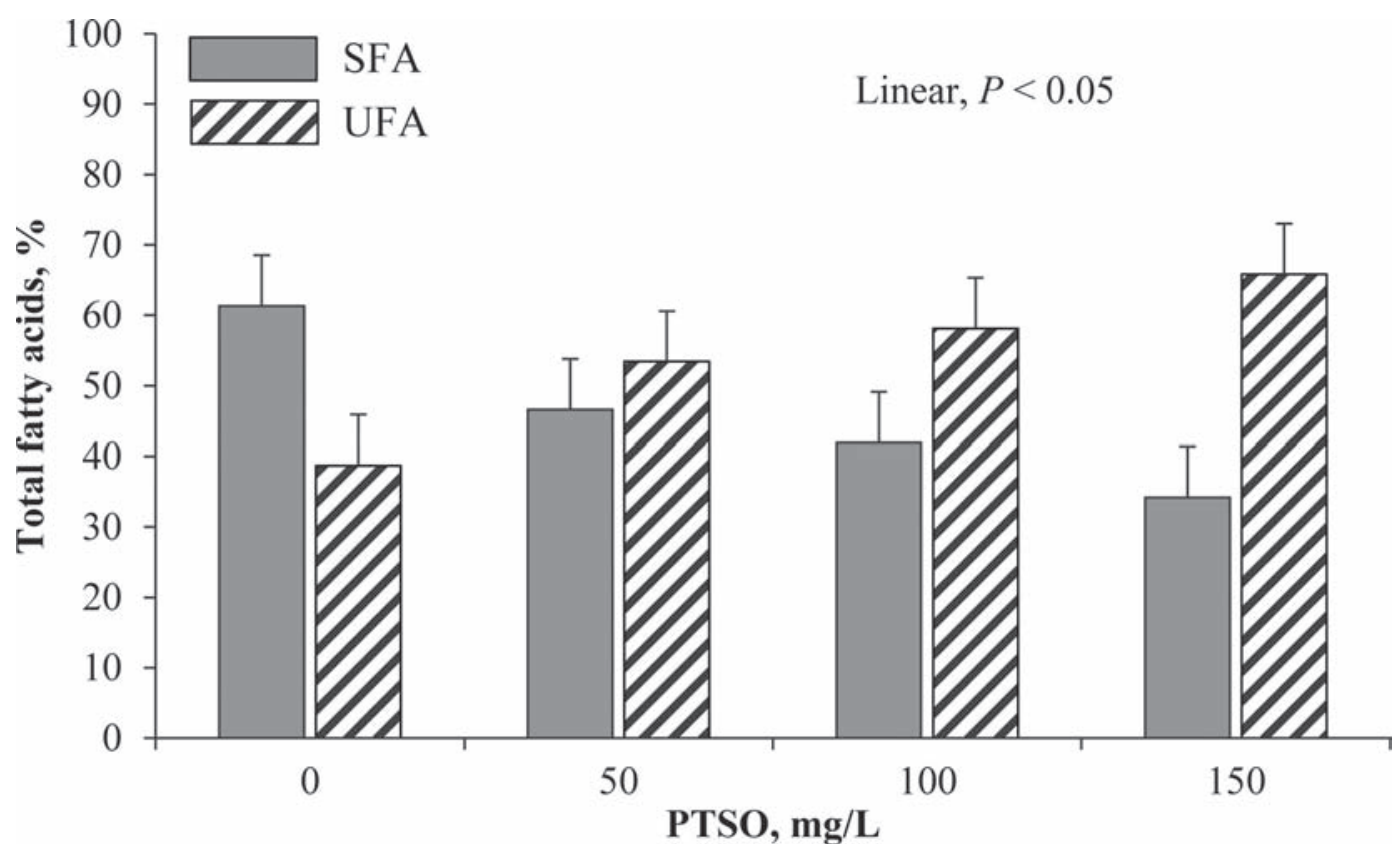

Figure 2. Linear responses $(P=0.003)$ of saturated and unsaturated fatty acids (SFA and UFA, respectively; \% of total FA) to increasing dose of propyl-propane thiosulfonate (PTSO; 0, 50, 100, and $150 \mathrm{mg} / \mathrm{L}$ ) at 24-h effluent in a dual-flow continuous culture (experiment 2).

\section{CONCLUSIONS}

In the first experiment, the high dose of PTSO (300 $\mathrm{mg} / \mathrm{L})$ dramatically reduced ruminal fermentation, suggesting that PTSO has strong antimicrobial activity. The second experiment was conducted to identify the effective dose of PTSO. Results suggested that the most effective dose of PTSO is between 50 and $100 \mathrm{mg} / \mathrm{L}$, wherein ruminal fermentation changed in a direction consistent with higher propionate molar proportion, increased UFA flow, and reduced SFA and trans-10, cis-12 CLA concentrations.

\section{ACKNOWLEDGMENTS}

This manuscript is based on research supported by Pancosma SA (Geneva, Switzerland); Andreas Foskolos received a scholarship for postgraduate studies from the State Scholarship Foundation of Greece (www.iky.gr).

\section{REFERENCES}

Allison, M. J., and M. P. Bryant. 1963. Biosynthesis of branched-chain amino acids from branched-chain fatty acids by rumen bacteria. Arch. Biochem. Biophys. 101:269-277.

Annison, E. F. 1954. Some observations on volatile fatty acids in the sheep's rumen. Biochem. J. 57:400-405.

AOAC. 1990. Official Methods of Analysis. 15th ed. Assoc. Off. Anal. Chem., Arlington, VA.

Bauman, D. E., and J. M. Griinari. 2003. Nutritional regulation of milk fat synthesis. Annu. Rev. Nutr. 23:203-227.
Bryant, M. P., and R. N. Doetsch. 1955. Factors necessary for the growth of Bacteroides succinogenes in the volatile acid fraction of rumen fluid. J. Dairy Sci. 38:340-350.

Busquet, M., S. Calsamiglia, A. Ferret, P. W. Cardozo, and C. Kamel. 2005a. Effects of cinnamaldehyde and garlic oil on rumen microbial fermentation in a dual flow continuous culture. J. Dairy Sci. 88:2508-2516

Busquet, M., S. Calsamiglia, A. Ferret, M. D. Carro, and C. Kamel. 2005b. Effect of garlic oil and four of its compounds on rumen microbial fermentation. J. Dairy Sci. 88:4393-4404.

Busquet, M., S. Calsamiglia, A. Ferret, and C. Kamel. 2006. Plant extracts affect in vitro rumen microbial fermentation. J. Dairy Sci. 89:761-771.

Calsamiglia, S., M. Busquet, P. W. Cardozo, L. Castillejos, and A. Ferret. 2007. Invited review: Essential oils as modifiers of rumen microbial fermentation. J. Dairy Sci. 90:2580-2595.

Cardozo, P. W., S. Calsamiglia, A. Ferret, and C. Kamel. 2004. Effects of natural plant extracts on ruminal protein degradation and fermentation profiles in continuous culture. J. Anim. Sci. 82:3230-3236.

Castillejos, L., S. Calsamiglia, and A. Ferret. 2006. Effect of essential oil active compounds on rumen microbial fermentation and nutrient flow in in vitro systems. J. Dairy Sci. 89:2649-2658.

Chaney, A. L., and E. P. Marbach. 1962. Modified reagents for determination of urea and ammonia. Clin. Chem. 8:130-132.

Chilliard, Y., F. Glasser, A. Ferlay, L. Bernard, J. Rouel, and M. Doreau. 2007. Diet, rumen biohydrogenation and nutritional quality of cow and goat milk fat. Eur. J. Lipid Sci. Technol. 109:828855.

Chilliard, Y., J. Rouel, A. Ferlay, L. Bernard, P. Gaborit, K. RaynalLjutovac, and A. Lauret. 2006. Optimizing goat's milk and cheese fatty acid composition. Pages 251-312 in Improving the Fat Content of Foods. C. Williams and J. Buttriss, ed. Woodhead Publishing Limited, Cambridge, UK.

Cowan, M. M. 1999. Plant products as antimicrobial agents. Clin. Microbiol. Rev. 12:564-582.

Donius, D. A., M. E. Simpson, and P. B. Marsh. 1976. Effect of monensin fed with forage on digestion and the ruminal ecosystem of steers. J. Anim. Sci. 42:229-234. 
European Commission. 2003. Regulation (EC) No. 1831/2003 of the European parliament and of the council of 22 September 2003 on additives for use in animal nutrition. Off. J. L268:229-243.

Falconer, M. L., and R. J. Wallace. 1998. Variation in proteinase activities in the rumen. J. Appl. Microbiol. 84:377-382.

Ferme, D., M. Banjac, S. Calsamiglia, M. Busquet, C. Kamel, and G. Avgustin. 2004. The effects of plant extracts on microbial community structure in a rumen-simulating continuous-culture system as revealed by molecular profiling. Folia Microbiol. (Praha) 49:151-155.

Fuentes, M. C., S. Calsamiglia, P. W. Cardozo, and B. Vlaeminck. 2009. Effect of $\mathrm{pH}$ and level of concentrate in the diet on the production of biohydrogenation intermediates in a dual-flow continuous culture. J. Dairy Sci. 92:4456-4466.

Fujisawa, H., K. Suma, K. Origuchi, H. Kumagai, T. Seki, and T. Ariga. 2008. Biological and chemical stability of garlic-derived allicin. J. Agric. Food Chem. 56:4229-4235.

Givens, D. I., and K. J. Shingfield. 2006. Optimizing dairy milk fatty acid composition. Pages 252-280 in Improving the Fat Content of Foods. C. Williams and J. Buttriss, ed. Woodhead Publishing Ltd., Cambridge, UK.

Harfoot, C. G., and G. P. Hazlewood. 1997. Lipid metabolism in the rumen. Pages 382-426 in The Rumen Microbial Ecosystem. 2nd ed. P. N. Hobson and C. S. Stewart, ed. Blackie Academic \& Professional, London, UK.

Hoover, W. H., B. A. Crooker, and C. J. Sniffen. 1976. Effects of differential solid-liquid removal rates on protozoa numbers in continuous cultures of rumen contents. J. Anim. Sci. 43:528-534.

Jenkins, T. C., R. J. Wallace, P. J. Moate, and E. E. Mosley. 2008. Board invited review: Recent advances in biohydrogenation of unsaturated fatty acids within the rumen microbial ecosystem. J. Anim. Sci. 86:397-412.

Jouany, J. 1982. Volatile fatty acid and alcohol determination in digestive contents, silage juices, bacterial cultures and anaerobic fermentor contents. Sci. Aliments 2:131-134.

Lang, G., and G. Buchbauer. 2012. A review on recent research results (2008-2010) on essential oils as antimicrobials and antifungals. Flavour Frag. J. 27:13-39.

Lara Cambil, A., and P. Garcia-Pareja, inventors. 2006. Use of extracts and compounds of allium genus plants as preservatives in the food and agri-food industries. S. L. Mousala, assignee. European Patent Office Patent No. 1721534 A1.

Lawson, L. D., and C. D. Gardner. 2005. Composition, stability, and bioavailability of garlic products used in a clinical trial. J. Agric. Food Chem. 53:6254-6261.

Littell, R. C., P. R. Henry, and C. B. Ammerman. 1998. Statistical analysis of repeated measures data using SAS procedures. J. Anim. Sci. 76:1216-1231.

Lourenço, M., E. Ramos-Morales, and R. J. Wallace. 2010. The role of microbes in rumen lipolysis and biohydrogenation and their manipulation. Animal 4:1008-1023.

Makkar, H. P. S., and K. Becker. 1999. Purine quantification in digesta from ruminants by spectrophotometric and HPLC methods. Br. J. Nutr. 81:107-112.
Martínez-Fernández, G., L. Abecia, A. I. Martín-García, E. RamosMorales, G. Hervás, E. Molina-Alcaide, and D. R. Yáñez-Ruiz. 2013. In vitro-in vivo study on the effects of plant compounds on rumen fermentation, microbial abundances and methane emissions in goats. Animal 7:1925-1934.

McKain, N., K. J. Shingfield, and R. J. Wallace. 2010. Metabolism of conjugated linoleic acids and 18:1 fatty acids by ruminal bacteria: products and mechanisms. Microbiology 156:579-588.

Moss, A. R., J.-P. Jouany, and J. Newbold. 2000. Methane production by ruminants: Its contribution to global warming. Ann. Zootech. 49:231-253.

Ramos-Morales, E., G. Martínez-Fernández, L. Abecia, A. I. MartinGarcía, E. Molina-Alcaide, and D. R. Yáñez-Ruiz. 2013. Garlic derived compounds modify ruminal fatty acid biohydrogenation and induce shifts in the Butyrivibrio community in continuous-culture fermenters. Anim. Feed Sci. Technol. 184:38-48.

Ruiz, R., M. P. García, A. Lara, and L. A. Rubio. 2010. Garlic derivatives (PTS and PTS-O) differently affect the ecology of swine faecal microbiota in vitro. Vet. Microbiol. 144:110-117.

Russell, J. B., and H. J. Strobel. 1988. Effects of additives on in vitro ruminal fermentation: A comparison of monensin and bacitracin, another gram-positive antibiotic. J. Anim. Sci. 66:552-558.

Russell, J. B., and H. J. Strobel. 1989. Effect of ionophores on ruminal fermentation. Appl. Environ. Microbiol. 55:1-6.

Stern, M. D., and W. H. Hoover. 1990. The dual-flow continuous system. Pages 17-32 in Proc. Continuous Culture Fermenters: Frustration or Fermentation. Northeast ADSA-ASAS Regional meeting. W.H. Miner Agricultural Research Institute, Chazy, NY.

Van Soest, P. J., J. B. Robertson, and B. A. Lewis. 1991. Methods for dietary fiber, neutral detergent fiber, and nonstarch polysaccharides in relation to animal nutrition. J. Dairy Sci. 74:3583-3597.

Vlaeminck, B., T. Braeckman, and V. Fievez. 2014. Rumen metabolism of 22:6n-3 in vitro is dependent on its concentration and inoculum size, but less dependent on substrate carbohydrate composition. Lipids 49:517-525.

Wallace, R. J., J. W. Czerkawski, and G. Breckenridge. 1981. Effect of monensin on the fermentation of basal rations in the Rumen Simulation Technique (Rusitec). Br. J. Nutr. 46:131-148.

Wallace, R. J., N. McKain, K. J. Shingfield, and E. Devillard. 2007. Isomers of conjugated linoleic acids are synthesized via different mechanisms in ruminal digesta and bacteria. J. Lipid Res. 48:2247-2254.

Weller, R. A., and A. F. Pilgrim. 1974. Passage of protozoa and volatile fatty acids from the rumen of the sheep and from a continuous in vitro fermentation system. Br. J. Nutr. 32:341-351.

Whitehouse, N. L., V. M. Olson, C. G. Schwab, W. R. Chesbro, K. D. Cunningham, and T. Lykos. 1994. Improved techniques for dissociating particle-associated mixed ruminal microorganisms from ruminal digesta solids. J. Anim. Sci. 72:1335-1343.

Winter, K. A., R. R. Johnson, and B. A. Dehority. 1964. Metabolism of urea nitrogen by mixed cultures of rumen bacteria grown on cellulose. J. Dairy Sci. 47:793-797. 